\title{
Readiness the Soul Cadres in the Handling of Violence Behavior when the Release of Pasung in Kokop Bangkalan
}

\section{Menyiapkan Kader Jiwa Dalam Penanganan Perilaku Kekerasan Saat Pelepasan Pasung Di Kokop Bangkalan}

\author{
Muhammad Suhron ${ }^{a, *} \&$ Ah. Yusuf ${ }^{b}$ \\ ${ }^{a}$ Program Studi Keperawatan, STIKES Ngudia Husada Madura, Bangkalan, Indonesia \\ ${ }^{b}$ Fakultas Keperawatan, Universitas Airlangga, Surabaya, Indonesia
}

\begin{abstract}
People with mental disorders (ODGJ) after pasung are defined as ODGJ who have been freed from confinement and referred to the hospital. One way of handling (ODGJ) is post pasung by involving mental cadres in handling violent behavior in people with mental disorders (ODGJ) after pasung. The purpose of this Community Service is to prepare soul cadres in handling violent behavior during the release of pasung. This community service was carried out in November 2019 with the target of soul cadres in Bangkalan Kokop. The team came from the Nursing Study Program at Stikes Ngudia Husada Madura, and the Faculty of Nursing, Airlangga University and the Kokop Community Health Center. This activity consists of a preparatory stage including an assessment / assessment and techniques for handling violent behavior by mental cadres in releasing pasung patients.
\end{abstract}

\begin{abstract}
Abstrak
Orang dengan gangguan jiwa (ODGJ) pasca pasung diartikan ODGJ yang sudah terbebas dari pemasungan dan dirujuk ke rumah sakit, Salah satu cara penanganan (ODGJ) pasca pasung dengan melibatkan Kader jiwa dalam menangani perilaku kekerasan pada Orang dengan gangguan jiwa (ODGJ) pasca pasung. Tujuan Pengabdian Masyarakat ini yaitu untuk menyiapkan kader jiwa dalam penanganan perilaku kekerasan saat pelepasan pasung. Pengabdian masyarakat ini dilakukan pada bulan November 2019 dengan sasaran kader jiwa di Kokop Bangkalan. Tim berasal dari Program Studi Keperawatan Stikes Ngudia Husada Madura, dan Fakultas Keperawatan, Universitas Airlangga serta puskesmas Kokop. Kegiatan ini terdiri dari tahap persiapan meliputi pengkajian/assesment dan tekhnik penanganan perilaku kekerasan oleh kader jiwa dalam pelepasan pasien pasung.
\end{abstract}

(C) 2021 Author(s).

Keywords: ODGJ; pasung; violent behavior; soul cadre; empowerment.

\section{Pendahuluan}

Orang dengan gangguan jiwa (ODGJ) pasca pasung diartikan ODGJ yang sudah terbebas dari pemasungan dan dirujuk ke rumah sakit, setelah mendapatkan perawatan dari rumah sakit dikembalikan kepada kader Jiwanya. Provinsi Jawa Timur mencanangkan bebas pasung 2019 dengan program e-pasung sebagai upaya untuk mensukseskan program bebas pasung. Gangguan jiwa berat psikotik yang dipasung sebanyak 2.090 orang dan 727 di antaranya masih pasung, 405 perawatan sisanya sudah bebas pasung (Dinas Sosial Propinsi Jawa Timur, 2016). Namun permasalahan muncul yaitu perilaku kekerasan dalam merawatnya, Intervensi diberikan lebih berfokus kepada

\footnotetext{
* Corresponding author:

E-mail address: dsuhron@yahoo.co.id (Muhammad Suhron)
} 
bagaimana kader Jiwa dapat mempertahankan kepada status kemandirian dan fokus pada perilaku kekerasannya tersebut (Keliat, 2013). Hasil Wawancara awal dengan 10 Kader jiwa didapatkan data bahwa 20\% Kader jiwa mengatakan siapa yang akan bertanggungjawab keberlanjutan pengobatan pasien, $10 \%$ Kader jiwa mengatakan khawatir mengenai perlindungan terhadap masyarakat jika terjadi perilaku kekerasan yang dilakukan ODGJ pasca pasung sebanyak 20\%, 20\% kader Jiwa mengatakan kesulitan dalam perawatan pasien mendapat pengobatan di rumah sebanyak 20\%. Hal ini menunjukkan ketidaksiapan kader Jiwa merawat ODGJ pasca pasung yang mengalami perilaku kekerasan. (Departemen Kesehatan RI, 2013; Departemen Kesehatan RI, 2018).

Ketidaksiapan kader Jiwa merawat ODGJ pasca pasung disebabkan kegagalan perawatan kader Jiwa sehingga dilakukan pemasungan kembali. Meningkatkan perilaku kekerasan oleh kader Jiwa mutlak dibutuhkan untuk merawat ODGJ pasca pasung. Perilaku kekerasan tanpa Situation Awareness, mengakibatkan perilaku kekerasan kurang untuk merawat secara komprehensif. Pengabdian masyarakat ini bertujuan menyiapkan kader jiwa dalam penanganan perilaku kekerasan saat pelepasan pasung dengan berbasis Model Of Treatment Readiness (Howel \& Day, 2002), dengan cara merawat menggunakan teori Caring Menurut Kristen Swanson (1991) (Suhron, 2018). Kebaharuan yang direncanakan ada kebaharuan Content dan mekanisme. Dalam penelitian yang pertama adalah kebaharuan Content yaitu berbasis Model Of Treatment Readiness (Howel \& Day, 2002),

\section{Metode}

Kegiatan pengabdian kepada masyarakat ini dilakukan pada bulan November 2019 yang bertempat di daerah desa Kokop Kecamatan Kokop Kabupaten Bangkalan-Madura. Sasaran Pengabdian adalah Kader Jiwa di daerah Kokop. Tim pengabdian berasal dari Program Studi keperawatan, Stikes Ngudia Husada Madura, dan Fakultas Keperawatan, Universitas Airlangga, Surabaya, Indonesia yang memiliki kepakaran dalam Kesehatan Jiwa Masyarakat.

Kegiatan ini terdiri dari tahap persiapan dan pelaksanaan kepada masyarakat khususnya Kader Jiwa. Pada Tahap persiapan, dilakukan screening pada kader jiwa, pengurusan administrasi dan perizinan, penyusunan media dalam menyiapkan kader jiwa dalam bentuk cara assessment perilaku kekerasan, identifikasi dini perilaku kekerasan, ceramah, tekhnik demonstrasi penanganan perilaku kekerasan oleh kader jiwa dalam pelepasan pasien pasung. Pada tahap pelaksanaan dilakukan penyuluhan dalam bentuk ceramah, Fokus Group Discussion (FGD) dan pembagian indicator assessment perilaku kekerasan dan tekhnik penanganan perilaku kekerasan dalam pelepasan pasien pasung.

\section{Hasil dan Pembahasan}

Hasil Focus Group Discussion (FGD) kader: Kehadiran secara fisik dan psikologis dibutuhkan dalam merawat ODGJ pasca pasung, karena pasien ODGJ pasca pasung membutuhkan interaksi dalam kesehariannya untuk mendukung pengobatan. Keberadaan kader jiwa dalam keluarga dalam mendukung perawatan sangat dibutuhkan karena pasien ODGJ pasca pasung belum bias mandiri seutuhnya. Diperlukan pemberian informasi kepada keluarga tentang hal perawatan dan pengobatan ODGJ pasca pasung, tokoh masyarakat menyampaikan keputusan masyarakat membantu pasien ODGJ pasca pasung untuk dapat bersosialisasi kembali dilingkungan sekitar. Diperlukan partisipasi aktif dari tokoh masyarakat sekitar dalam menjalankan Perawatan dan pengobatan, sedangkan dari tenaga kesehatan program pelayanan kesehatan jiwa di puskesmas dalam bentuk posyandu jiwa sudah ada (baru terbentuk) namun belum berjalan optimal.

Kader dan Keluarga: Pengambil keputusan dalam suatu keluarga sangat menentukan pengambilan keputusan sehingga seseorang sebagai penentu kebijakan dibutuhkan dalam suatu keluarga, tentunya dengan keputusan semua anggota keluarga untuk mendukung perawatan ODGJ pasca pasung. Keluarga dapat hadir dan siap membantu saat dibutuhkan ODGJ pasca pasung. keputusan Keluarga memberikan kesempatan kepada ODGJ agar bisa dibantu untuk mandiri seperti kebutuhan ADL ODGJ.

Kader dan Masyarakat: Pengambilan keputusan tidak terlepas dengan musyawarah dengan tokoh masyarakat sehingga masyarakat ikut membantu dalam pengambilan keputusan. Tokoh masyarakat menjadi pengambilan keputusan dalam mendukung proses sosialisasi perawatan di lingkungan setempat 
Kader dan Puskesmas/petugas kesehatan: Dalam pengambilan keputusan perawatan dan pengobatan ke puskesmas, diperlukan seseorang sebagai penentu kebijakan terkait dengan proses perawatan dan pengobatan yang berkoordinasi dengan puskesmas sehingga proses perawatan dapat berjalan dengan kondusif dan terjadwal

Kader dalam pelaksanaan posyandu jiwa sebagai wadah dapat mendukung dalam pengambilan keputusan untuk perawatan ODGJ pasca pasung. menurut keluarga Pengambilan keputusan dibutuhkan pemilihan strategi yang tepat sesuai dengan kebutuhan ODGJ pasca pasung dalam proses perawatan sehingga strategi yang digunakan dapat berjalan dengan kondusif dan terjadwal, adapun dampak pemilihan strategi yang kurang tepat akan berakibat repasung kembali, dikarenakan kebutuhan ODGJ dalam perawatan tidak tercapai optimal masyarakat.

Kader dan tokoh masyarakat dalam pemilihan strategi untuk pengambilan keputusan menjadi hal yang sangat penting, mengingat masyarakat sebagai pemangku kebijakan, norma, adat di suatu daerah akan sangat membantu pemilihan (Suhron, Yusuf, \& Subarniati, 2019)

Kader dalam strategi untuk proses pengambilan keputusan yang tepat tidak melanggar norma, adat setempat. Banyak yang sebelumnya dianggap malu mempunyai keluarga ODGJ. Stigma negative (malu) yang melekat pada keluarga dapat dibantu melalui tokoh masyarakat untuk merubah stigma menjadi positif (Suhron, et.al, 2020), karena hal ini akan, hasil diskusi berdampak pada pemilihan strategi dalam pengambilan keputusan petugas kesehatan menyatakan Program pelayanan dalam posyandu jiwa sebagai garda utama dapat memberikan informasi secara dini dalam menjaring aspirasi dan keluhan permasalahan keluarga dalam pemilihan strategi untuk pengambilan keputusan, sedangkan keluarga mengatakan Kebersamaan bersama keluarga dengan pola komunikasi yang terapeutik dibutuhkan ODGJ pasca pasung, mengingat keluarga yang paling dekat dengan ODGJ, Diperlukan informasi pola komunikasi yang efektif dan terapeutik, kepada keluarga dengan mengajarkan tahapan komunikasi yaitu fase orientasi, fase kerja dan terminasi tokoh Masyarakat mengatakan Perlu partisipasi tokoh agama ,tokoh masyarakat, beserta aparatur desa bersinergi mengingat tindakan yang dilakukan kepada ODGJ tidak terlepas oleh kebijakan, Norma dan adat setempat, petugas kesehatan Puskesmas. Perlu adanya koordinasi dengan pihak petugas kesehatan dan pelayanan kesehatan puskesmas sebagai langkah antisipatif tindakan dalam perawatan dan pengobatan ODGJ pasca pasung dengan melalui posyandu jiwa

Secara umum kader menyiapkan perilaku kekerasan merawat ODGJ pasca pasung berbasis Model of Treatment Readiness yang sangat ditentukan oleh factor keluarga, pasien dan pelayanan kesehatan.

Kader mengeksplorasi faktor keluarga, pasien dan pelayanan kesehatan. keyakinan keluarga untuk siap merawat ODGJ pasca pasung berdasarkan kesadaran akan situasi yang dihadapi keluarga setelah ODGJ pasca pasung agar ODGJ pasung dapat pulih kembali dan dapat bersosialisasi di lingkungan dan produktif (Suhron, 2018).

Kader menginformasikan pengetahuan keluarga dalam menghadapi konflik dengan mencari permasalahan dalam merawat ODGJ sehingga informasi itu dapat dijadikan sebagai kesepakatan bersama dan tolak ukur dalam menyelesaikan masalah saat perawatan. (Marasabessy \& Suhron, 2020).

Kader bersamaan keluarga mutlak dibutuhkan dalam proses perawatan dengan memberikan kesempatan yang konstruktif dan fleksibel dalam menerapkan perawatan dan berusaha untuk memberikan kebutuhan ODGJ pasca pasung sesuai dengan nilai budaya dan kebiasaan sehari-hari agar self esteem meningkat (Suhron, 2017; Suhron 2016). Kesadaran merawat ODGJ pasca pasung dengan tetap mengedepankan nilai situasi dan privasi serta menjaga ODGJ pasca pasung harga dirinya terjaga dengan cara melibatkan ODGJ pasca pasung setiap mengambil keputusan istilahnya "memanusiakan manusia" (Yusuf, Sulaihah, Nihayati, \& Suhron, 2020). Keluarga ODGJ mempunyai kemampuan dalam mengevaluasi setiap perawatan yang dilakukannya, terkait hal informasi yang dibutuhkan oleh keluarga, cara mendapatkan informasi tersebut hingga hal yang dapat mendukung proses perawatan, adapun kesadaran akan. situasi ini menjadi hal kebiasaan keluarga dalam mengahadapi permasalahan selama proses perawatan (Suhron \& Zainiyah, 2020). 
Suhron, et.al | Mattawang: Jurnal Pengabdian Masyarakat, 2021, 2(1): 14-18

Tabel 1. Karakteristik sosio-demografi peserta $(n=13)$

\begin{tabular}{|c|c|c|}
\hline Variabel & Frekuensi & $\%$ \\
\hline \multicolumn{3}{|l|}{ Jenis kelamin } \\
\hline Laki-Laki & 9 & 69,2 \\
\hline Perempuan & 4 & 30,8 \\
\hline \multicolumn{3}{|l|}{ Usia } \\
\hline Bekerja & 26.20 tahun & \\
\hline Berada Dirumah & 28.40 Tahun & \\
\hline \multicolumn{3}{|l|}{ Status perkawinan } \\
\hline Cerai / belum kawin & 8 & 61,5 \\
\hline Kawin & 3 & 38,5 \\
\hline \multicolumn{3}{|l|}{ Lama menjadi Kader JIWA } \\
\hline 1 bulan & 6 & 46,1 \\
\hline 2 bulan & 3 & 23,0 \\
\hline 3 bulan & 4 & 30,8 \\
\hline \multicolumn{3}{|l|}{ Pekerjaan } \\
\hline Waktu penuh/part time & 4 & 30,8 \\
\hline Pengangguran/ student & 9 & 69,2 \\
\hline \multicolumn{3}{|l|}{ Pendidikan } \\
\hline Sekolah Dasar & 6 & 46,1 \\
\hline Sekolah menengah pertama (SMP) & 2 & 15,4 \\
\hline Sekolah menengah atas (SMA) & 5 & 38,5 \\
\hline \multicolumn{3}{|l|}{ Tempat Tinggal } \\
\hline Perkotaan & 9 & 30,8 \\
\hline Perdesaaan & 4 & 69,2 \\
\hline
\end{tabular}
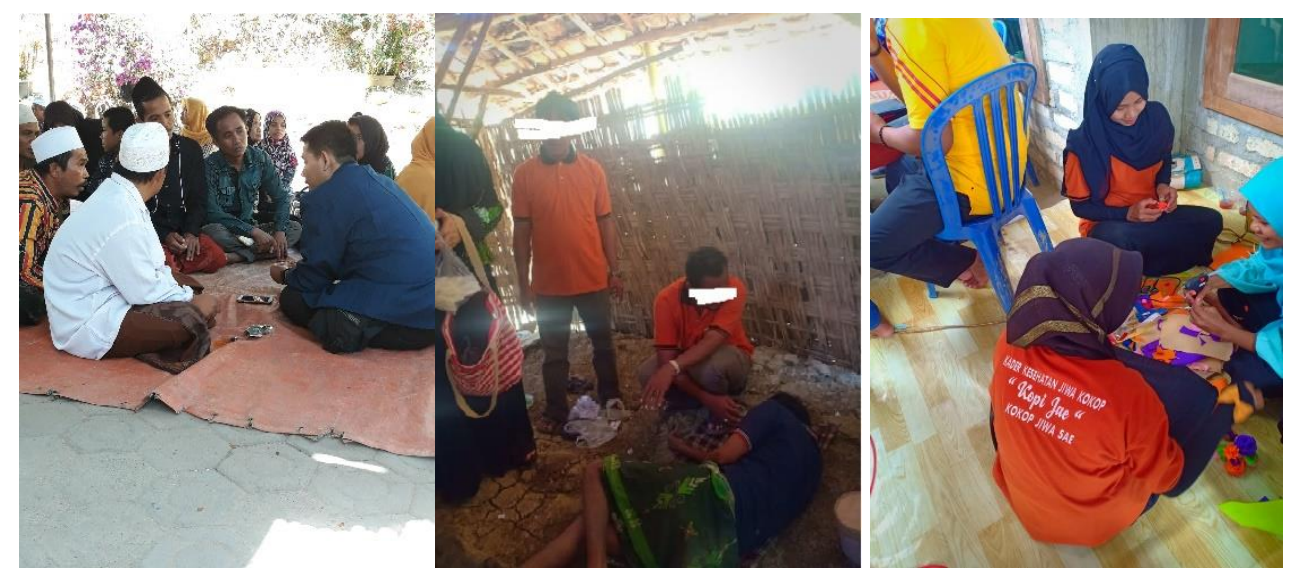

Fig. 1. Kegiatan pelatihan tekhnik Assesment ODGJ pasung 


\section{Kesimpulan}

Pelaksanaan Kegiatan Pengabdian kepada masyarakat ini berjalan lancer, baik pada tahapan persiapan maupun pelaksanaan kegiatan. Kegiatan pengabdian berupa assessment dan menyiapkan kader jiwa dalam penanganan perilaku kekerasan pada ODGJ pasung di desa Kokop kecamatan Bangkalan Madura. Sehingga kader jiwa memiliki kemampuan dan kompetensi yang terstruktur dan sesuai dengan tekhnik assessment dan penanganan perilaku kekerasan ODGJ pasung dengan benar, hal ini karena kader jiwa garda terdepan dalam proses assessment informasi dan perawatan penanganan perilaku kekerasan ODGJ pasung.

\section{Acknowledgements}

Kami mengucapkan terima kasih kepada Program Studi keperawatan, Stikes Ngudia Husada Madura, dan Fakultas Keperawatan, Universitas Airlangga, Surabaya, Indonesia yang memiliki kepakaran dalam Kesehatan Jiwa Masyarakat dan Puskesmas Kokop Bangkalan Madura. Khususnya Kepala Puskesmas dan Lurah Kokop yang berkontribusi secara langsung maupun tidak langsung dalam kegiatan pengabdian masyarakat ini.

\section{References}

Departemen Kesehatan RI. 2013. Riset Kesehatan Dasar. Jakarta: Badan Penelitian dan pengembangan Kesehatan Kementrian Kesehatan RI.

Departemen Kesehatan RI. 2018. Riset Kesehatan Dasar. Jakarta: Badan Penelitian dan pengembangan Kesehatan Kementrian Kesehatan RI.

Dinas Sosial Propinsi Jawa Timur. (2016). Bebas Pasung 2019 dengan Program e-Pasung Sebagai Upaya Untuk Mensukseskan Program Pasung. Surabaya: Dinas Sosial Propinsi Jawa Timur. Disitasi 2 oktober 2018

Howells, K., \& Day, A. (2003). Readiness for anger management: Clinical and theoretical issues. Clinical psychology review, 23(2), 319-337.

Marasabessy, N.B. \& Suhron, M. 2020. Stress family experience and profiles of Tumor Necrosis Factor Alpha and Interleukin-10 of Nuaulu Tribe Community with Hunting Activity in Mesoendemic Area of Malaria. Systematic Reviews in Pharmacy, 11(11): 1886-1891.

Suhron, M. (2016). Asuhan keperawatan konsep diri: Self esteem. Ponorogo: Unmuh Ponorogo Press.

Suhron, M. (2017). Asuhan keperawatan jiwa konsep self esteem. Jakarta: Mitra Wacana Media.

Suhron, M., Sulaihah, S., \& Yusuf, A. H. (2017). Model of Potential Strengthening and Family Roles in Improving Family Members for ODGJ Adaptability. In Proceeding of the 2nd International Symposium of Public Health (pp. 344-351). Faculty of Public Health Universitas Airlangga.

Suhron, M., Yusuf, A., \& Subarniati, R. (2019). Assessment of Stress Reactions and Identification of Family Experiences in Primary Care Post Restrain Schizophrenia in East Java Indonesia. Mix Method: Sequential Explanatory. Indian Journal of Public Health Research \& Development, 10(12), 1849-1854.

Suhron, M. \& Zainiyah, Z. 2021. How were stress family and INSR (Insulin Receptor) expression in Polycystic Ovary Syndrome (PCOS) Insulin Resistant in Madurese Tribe?: Indonesia. Systematic Reviews in Pharmacy, 12(1), 170-175.

Suhron, M., Yusuf, A., Subarniati, R., Amir, F., \& Zainiyah, Z. (2020). How does forgiveness therapy versus emotion-focused therapy reduce violent behavior schizophrenia post restrain at East Java, Indonesia? International Journal of Public Health, 9(4), 314-319. 